\title{
Identification of productive clusters in the blueberry cultivation (Vaccinium corymbosum) in central Chile
}

\author{
Identificación de clústeres productivos en el cultivo de arándanos (Vaccinium corymbosum) en Chile \\ central
}

\section{Identificação de clusters produtivos no cultivo de mirtilo (Vaccinium corymbosum) no Chile central}

Carlos Mena ${ }^{1}$ (D)

Yony Ormazábal $^{1 *}$ (잉 (1)

Juan Carlos Cantillana ${ }^{2}$ (a) (D)

Lisandro $\mathrm{Roco}^{3}$ (a) (D)

Rev. Fac. Agron. (LUZ). 2022, 39(1): e223902

ISSN 2477-9407

DOI: https://doi.org/10.47280/RevFacAgron(LUZ).v39.n1.02

\section{Socieconomy}

Associate editor: Dra. Fatima Urdaneta

\begin{abstract}
${ }^{1}$ Center of Geomatics, Universidad de Talca, Talca 3460000, Chile.

${ }^{2}$ Faculty of Administration and Economics, Universidad Tecnológica Metropolitana, Santiago 8320000, Chile.

${ }^{3}$ Institute of Agricultural Economics, Faculty of Agricultural and Food Sciences, Universidad Austral de Chile, Valdivia 5090000, Chile.
\end{abstract}

Received: 06-05-2020

Accepted: 31-08-2021

Published: 16-12-2021

\section{Keywords:}

Agroindustry

$\mathrm{K}$ function

Geographical distribution

\begin{abstract}
The understanding of the productive characteristics and tendencies of fruit producer's territorial concentration can be explained starting from the singularities of the territory, the production techniques or the market conditions. This article analyzes the formation of clusters of blueberry producers in the Maule region in central Chile, based on the productive characteristics of the crops that include the technological levels, the age of the plantations and the size of the farms. For this, a two-step cluster analysis was performed to obtain homogeneous groups or conglomerates. The results obtained were analyzed in the ArcGIS software, using the Ripley K function, to determine their spatial concentration and to relate the spatial location of the orchards belonging to each cluster and their geographical distribution. The analysis indicates the existence of four clusters in the region, differing preferably by the sizes of the farms. The predominant technological level between the clusters identified is the intermediate, followed by the advanced. The clusters tend to generate spatial and geographic concentrations related with communication facilities and agroecological conditions (climate, soil, relief features). Results founded can improve focus of public efforts and private investments in the productive activity of blueberry cultivation.
\end{abstract}




\section{2-7 | Rev. Fac. Agron. (LUZ). 2022, 39(1): e223902. January - March. ISSN 2477-9407.}

\section{Resumen}

La comprensión de las características productivas y las tendencias de concentración territorial de los productores frutícolas se puede explicar a partir de las particularidades del territorio, las técnicas de producción o las condiciones del mercado. Este artículo analiza la formación de conglomerados de productores de arándano en la Región del Maule en el centro de Chile, basándose en las características productivas de los cultivos que incluyen el nivel tecnológico, la antigüedad de las plantaciones y el tamaño de los huertos. Para esto, se realizó un análisis de conglomerados de dos pasos para obtener grupos homogéneos. Los resultados obtenidos se analizaron en el software ArcGIS, utilizando la función K de Ripley, para determinar la concentración espacial y relacionar la ubicación espacial de los huertos pertenecientes a cada grupo y su distribución geográfica. Los análisis indican la existencia de cuatro conglomerados en la región, que se diferencian preferentemente por el tamaño de los huertos. El nivel tecnológico predominante entre los clústeres identificados es el intermedio, seguido del avanzado. Los clústeres tienden a generar concentraciones espaciales y geográficas relacionadas con la infraestructura de comunicación y con las condiciones agroecológicas (clima, suelo, características del relieve). Los resultados encontrados pueden mejorar el enfoque de los esfuerzos públicos y las inversiones privadas en la actividad productiva del cultivo del arándano.

Palabras clave: agroindustria; función K; distribución geográfica.

\section{Resumo}

A compreensão das características produtivas e tendências de concentração territorial dos fruticultores pode ser explicada a partir das particularidades do território, das técnicas de produção e das condições de mercado. Este artigo analisa a formação de clusters de produtores de mirtilo na região de Maule, no Chile central, com base nas características produtivas das lavouras que incluem o nível tecnológico, a idade das plantações e o tamanho das propriedades. Para isso, foi realizada uma análise de cluster em duas etapas para obter grupos ou conglomerados homogêneos. Os resultados obtidos foram analisados no software ArcGIS, utilizando a função Ripley K, para determinar a concentração e localização espacial dos pomares pertencentes a cada cluster, assim como a sua distribuição geográfica. As análises indicam a existência de quatro clusters na região, diferenciando-se preferencialmente pelo tamanho das propriedades. O nível tecnológico predominante entre os clusters identificados é intermediário, seguido do avançado. Os clusters tendem a gerar concentrações espaciais e geográficas relacionadas com as infraestruturas de comunicação e as condições agroecológicas (clima, solo, características de relevo). Os resultados encontrados podem melhorar o foco de esforços públicos e investimentos privados da atividade produtiva da cultura do mirtilo.

Palavras-chave: agroindústrias; função K; distribuição geográfica.

\section{Introduction}

The Maule region has a Mediterranean climate zone that allows the development of an important agro-industrial and forestry activity, with the fruit sector being one of the most relevant (Maturana et al., 2019; Soza-Amigo, 2011). The blueberry cultivation has increased rapidly in central Chile in the last years, reaching the 5,942.8 ha planted in the region (ODEPA and CIREN, 2019) which correspond to $32.3 \%$ of the national total, most of it $(79.8 \%)$ is being destined preferably for export as fresh fruit shipped to the northern hemisphere. Currently, Chile is among the main producing countries of blueberries, positioning itself as the third producer and the second exporter in the world (Almonacid, 2018). As for fresh blueberries, it is the world's leading exporter and the main supplier of this fruit in the winter of the northern hemisphere. The harvest in that hemisphere ends in October, allowing the entry of the Chilean production from the counter-season harvest in response to the growing demand for fresh blueberry.

Chilean blueberry exports are mainly destined for the United States and Canada (51.236 t), followed by Europe (16.570 t) and Asia (6.456 t), according to statistics of the Chilean Blueberry Committee, 2020. This situation is consistent with a Chilean productive sector that has based its insertion in the world economy on its comparative advantages and an important processes of land transformation for generating new productive and territorial dynamics (Riffo, 2018). On the other hand, the blueberry cultivation in central Chile at the Maule region has been studied preferably from specific productive approaches, with an emphasis on the cultivars planted, the production characteristics or the technology used; however, no specific studies have been carried out on the configuration of clusters or on the agglomeration conditions of productive farms, which makes it necessary to review the spatial and geographical characteristics of the productive units that make up this fruit sector.

Studies focused on the analysis of the distribution of agricultural activities in the territory have shown that there are local socioeconomic factors that explain the patterns of land use conversion, in addition to the physical conditions of the territory where the location factors themselves described alone most of the diversity of the farms studied (Van Doorn \& Baker, 2007; Van de Steeg et al., 2009). However, the complexity of the economy in rural areas and its structure have not been sufficiently considered. One way to improve the study of this situation is the cluster approach, a methodology that can be applied to complex territorial scenarios where small producers dominate (Tapia et al., 2015).

The concept of cluster involves the idea of a set of companies in a given industry that follows the same or similar strategy (Lobos, 2006), where the close location of companies with each other can allow the generation of economies of scale (Ortega-Colomer et al., 2016). In this way, the formation of clusters allows companies to take advantage of agglomeration economies, obtaining multiple benefits (Vidal-Suñé \& Pezoa-Fuentes, 2012). Therefore, different studies have incorporated distance-based methods mainly in the evaluation of the concentrations of industries and economic activities. Duranton \& Overman (2005) used tests to study the location patterns of industries, based on distance. In Italy, Dominicis et al. (2007) considered geographical concentration to study both manufacturing and service industries. Marcon \& Puech (2003) incorporated distancebased methods in studies of companies' clusters, in addition to other methods derived from the Ripley K function.

The spatial analysis of multiple distance based on the Ripley $\mathrm{K}$ function is a good way to study the pattern of point data related to spatial elements. One of the outstanding characteristics of this analysis is that it summarizes the spatial dependency in a determined range of distances, also allowing to illustrate the changes in the spatial clustering or the dispersion of the entity centroids, when there is a change in the neighborhood size. In this way, authors from different countries have applied conglomerate analyzes to the study and classification of agricultural producers, management practices 
and ecosystem impacts (Acosta et al., 2014; Borja-Bravo et al., 2016; González et al., 2018; Carpio \& Urbano, 2019).

In Chile, Carmona \& Nahuehual (2009) analyzed the strategies of agricultural producers by comparing the size of production and their production systems, while Carrillo et al. (2011) characterized typologies of dairy production systems, using variables related to the technological level of producers. In the Maule region, Guerrero et al. (2015) studied plantations of European hazelnuts, recognizing the influence of environmental conditions among other factors, in the formation of conglomerates. Likewise, Lobos (2006) studied agricultural clusters (wine, fruit and wood) of the region from an economic perspective; and Fernández et al. (2019) studied groups of annual crop producers.

As observed, research on productive conglomerates has been a topic of interest in various fields in the last decade, covering academic, public and private interests (Duque et al., 2009), since the geographical concentration of companies and their economic implications is a key element, even more considering the conditions of agricultural competitiveness warned in the recent decade, together with the conditions generated by globalization and market instability (Castellanos et al., 2012). Thus, the possible existence of clusters in the different productive areas of a region constitutes a field of study that is directly related to the trend of concentration of economic activities in the territory (Garrocho et al., 2012).

The present study aimed to determine the characteristics of blueberry producing farms in the Maule region in terms of production conditions and their spatial distribution. In this way, the distinctive types of blueberry producing orchards in the region are analyzed, considering the criteria used in the studies reviewed, especially those related to productive characteristics, farm size and plantations age, also reviewing the spatial concentration of each of the clusters identified in the study.

\section{Materials and methods}

\section{Description of the study area}

The study area corresponds to the Maule region, where the highest concentration of blueberry orchards is found in the sectors of the Central Valley and to a lesser extent, in the marginal basins of the Coastal Cordillera and bottoms of Andean and Coastal valleys. These sectors present favorable conditions for the growth of blueberry with preferably acid soils, with a $\mathrm{pH}$ between 4.0-5.0, and textures sandy, sandy loam or clayey; characteristic situation of the area located between $35^{\circ}$ and $37^{\circ}$ South latitude, where also the physical conditions of the terrain are enhanced by a temperate Mediterranean climate with a prolonged dry season, mild winters and temperate springs (Sarricolea et al., 2017).

\section{Information collection techniques and population sample}

The blueberry producing orchards were geo-referenced by means of a field survey supported by GPS technology (Global Positioning System). Then, these places were located on a SPOTMaps color mosaic, used as a cartographic base cover. This mosaic was produced by Spot Image (https://www.intelligence-airbusds.com) from orthorectified SPOT-5 satellite images with spatial resolution of $2.5 \mathrm{~m}$ and with a geometric precision level that allowed to work on a cartographic base of scale 1:10,000. The production units were determined on the basis of the production orchards, identifying 202 validated producers by field work made at the end of the 2016 harvest season. A technical form to collect data referring to technical production variables was designed by a panel of experts including both professionals related to the cultivation of blueberries (agronomists and agricultural technicians) as well as geomatics specialists. The selection of variables considered aspects as the size of the producer and the type or variety of crops, as well as the production, irrigation and harvesting systems. In this way, the form included productive technical variables such as: types of plantations, yield, irrigation, mechanization of the harvest process, age of plantations, type of plant material, weed control mechanisms, plantation design and production systems; and was completed in the field by the interviewers in conjunction with each producer. This survey considered $93 \%$ of blueberry producers at the regional level with orchards over 1 ha of plantation. Thus, each one of the orchards was spatially represented as a point in the cartographical base according to its geographical coordinates. In addition, each one was linked with all its respective technical data collected with the field form, forming a GIS thematic layer used later to carry out the cluster analyses.

\section{Systematization of variables}

The orchards were characterized according to three parameters that represent and group the productive technical variables previously outlined. In this way, the following were considered as relevant factors:

a. Production size: expressed as the total hectares allocated by each producer to blueberry plantations and reflects the producer's investment capacity as well as the weight that can exert in the local market. It is a relevant variable given the dispersion of the cultivation areas, ranging for example from 1 to 140 ha of continuous crops (including various cultivars) for a same producer.

b. Age of the orchard: taken from the year of planting, it reflects the phase in which the production is within the yield curve presented by this fruit understanding that blueberry plants show their highest yield between 5 to 9 years of age (Retamales \& Hancock, 2012). Thus, this parameter allows identifying productive differences between orchards.

c. Technological Level (TL) of production: calculated based on the proposal made by Ormazábal et al. (2020), it allowed establishing differences about the incorporation of technology in the blueberries production for the orchards studied. This TL was estimated from technical parameters, considering the plant material used, the origin of this plant material, use of mulch, irrigation system, plantation design, use of ridges, type of weed control, technique of production and harvesting system. For each variable, alternatives ranked in ascending order were considered; then, to each variable a weight or weight was assigned according to its importance. The determination of hierarchies and weights was made by the panel of experts. Finally, the TL was determined using the weighted linear combination (WLC) technique by mean of the ArcGIS software. The final score gave rise to 3 categories, with TL1 being the high technology level, TL2 being the medium level and TL3 being the low level.

\section{Data analysis techniques}

A two-step cluster analysis was performed to obtain groups or conglomerates. One advantage of cluster analysis is that it can minimizes research bias by not specifying classes according to prespecified conceptions (Rosenberg \& Turvey, 1991). Two-step cluster analysis is an exploration tool to discover the natural groupings of a data set (Satish \& Bharadhwaj, 2010). Its unique characteristics, compared to other traditional clustering methods, are the following: an automatic procedure for the optimal number of clusters, the possibility of creating cluster models with both categorical and 
continuous variables, and the option of working with large data files (Pérez, 2011). The procedure is based on an algorithm that produces optimal results if all variables are independent, the continuous variables are normally distributed, and the categorical variables are multinomial; but it is a procedure that works reasonably well in the absence of these assumptions in larger samples (Hair et al., 2010). So, the conditions of the data were checked before the application of this tool (Rubio-Hurtado \& Vilà-Baños, 2017). The described procedure was performed using the SPSS Software.

The conglomerates or clusters obtained from the described analysis, were then analyzed using the Ripley $\mathrm{K}$ function to characterize their spatial distribution and identify trends in the concentration or dispersion of the orchards belonging to each one of them. Ripley K function is defined as:

$$
K(r)=N(r) / \lambda
$$

where $N(r)$ is the mean number of neighboring points within a circle of radius $r$ around any typical point of the pattern, and $\lambda$ is the intensity of the pattern (in most cases equivalent to the density of points). The function $\mathrm{K}$ is often defined by saying that the product $\lambda \mathrm{K}(\mathrm{r})$ is the average number of neighbors within a circle of radius $r$ around a typical individual of the pattern (De la Cruz, 2008). Therefore, it is expected that, if there is a regular pattern, the probability of finding one point near another is greater.

Finally, the clusters were visualized on a cartographical background based on the geomorphic units present in the region, to establish relationships between the position of each conglomerate and the environmental conditions where they are located.

\section{Results and discussion}

From the 202 blueberry producers interviewed and georeferenced in the Maule region, we obtained 4 groups or clusters with $84,12,53$ and 53 producers respectively (table 1).

Table 1. Number of producers (n) and proportion of regional total by cluster

\begin{tabular}{clcc}
\hline Cluster & \multicolumn{1}{c}{ Main characteristics } & $\begin{array}{c}\text { Number } \\
\text { of } \\
\text { producers }\end{array}$ & $\begin{array}{c}\text { \%o of the } \\
\text { planted area } \\
\text { in the region }\end{array}$ \\
\hline A & $\begin{array}{l}\text { Orchards of mayor size with a } \\
\text { preferably intermediate TL (TL2) }\end{array}$ & 84 & 65.7 \\
B & $\begin{array}{l}\text { Orchards of intermediate size } \\
\text { with an advanced or intermediate }\end{array}$ & 12 & 6.3 \\
TL (TL1, TL2) \\
C & $\begin{array}{l}\text { Orchards of small size with } \\
\text { a preferably intermediate TL } \\
\text { (TL2) }\end{array}$ & 53 & 15.7 \\
\hline D & $\begin{array}{l}\text { Orchards of small size with a } \\
\text { diverse TL }\end{array}$ & 53 & 12.3 \\
\hline
\end{tabular}

According to the graphic quality of the analysis, which is equivalent to a silhouette measure of the cohesion and separation of the clusters, the result is classified as good, equivalent to 0.7 . The clusters found show a clear tendency to differentiate based on the size of the orchards, a situation also noted in the work of Carmona \& Nahuelhual (2009).

Table 2 shows that cluster A has more than $50 \%$ of producers with TL2, which added to those corresponding to TL3 represent 84.4 $\%$ of this cluster wich on average, has orchards with 22.12 ha and plantations from 1982 to 2012. Cluster B concentrates preferably producers with TL1 and TL2 (91.6\%), an average area of 14.05 ha per orchard and plantations planted between 2002 and 2011. Cluster C concentrates $73.5 \%$ of producers with TL1 and TL2, an average area of 8.19 ha and plantations from 2001 to 2010. Finally, cluster D presents a more homogeneous distribution in terms of technology implementation with $35.8 \%$ in TL1, $37.7 \%$ in TL2 and $26.4 \%$ in TL3, the average area of these orchards reaches 6.37 ha with plantation years between 1987 and 2011.

Table 2. Characterization of identified clusters

\begin{tabular}{ccccccc}
\hline Cluster & \multicolumn{3}{c}{ TL (\%) } & $\begin{array}{c}\text { Years of the } \\
\text { plantations } \\
\text { (since }- \\
\text { until) }\end{array}$ & $\begin{array}{c}\text { Mean age } \\
\text { of the } \\
\text { orchards } \\
\text { (years) }\end{array}$ & $\begin{array}{c}\text { Size of the } \\
\text { orchards } \\
\text { (ha) }\end{array}$ \\
\hline A & 15.4 & 52.3 & 32.1 & $1982-2012$ & $12.5^{\mathrm{a}}$ & $22.12^{\mathrm{a}}$ \\
B & 41.6 & 50.0 & 8.3 & $2002-2011$ & $18.5^{\mathrm{b}}$ & $14.05^{\mathrm{b}}$ \\
C & 32.0 & 41.5 & 26.4 & $2001-2010$ & $12.2^{\mathrm{a}}$ & $8.19^{\mathrm{c}}$ \\
D & 35.8 & 37.7 & 26.4 & $1987-2011$ & $12.6^{\mathrm{a}}$ & $6.37^{\mathrm{c}}$ \\
\hline
\end{tabular}

$\mathrm{a}, \mathrm{b}, \mathrm{c}$ Means with different literals are significantly different $(\mathrm{p}<0.01)$.

There is a clear differentiation in the size of the orchards, where the average of cluster A almost quadruples that of cluster D; this predominance of larger orchards has been maintained over time considering that the plantation ages of cluster A are the widest, covering a time range of 20 years. It is possible that the differences regarding the productive life of different blueberry species may explain the tendency to maintain plantations of more than 20 years (based on more widespread yielding cultivars), in addition to the management applied by companies with greater investment capacity.

Clusters $\mathrm{B}$ and $\mathrm{C}$ have similarity in the plantation ages, but they are clearly differentiated by the orchards' size, appreciating a concentration in TL of higher hierarchy. Cluster D, on the other hand, would be representing smaller producers and possibly with a less capacity of reaction to market changes, which would explain, in this case, the wide range of plantation ages, slightly lower than that of cluster A, but apparently influenced by the lower capacity for plant renewal.

This latter group includes mostly producers attached to INDAP (Institute of Agricultural Development) or who receive productive support from PRODESALES (Local Development Programs), and their dispersion in terms of TL is consistent with the characterization carried out by González et al. (2016) regarding to variability in aspects such as the plantation framework, application of fertilizers, among others management aspects. Although a significant number of these producers receive this technical advice, the variability in the technological implementation for production and the wide dispersion in the ages of the orchards seem to indicate the need to reinforce such actions, especially in the producers of this group. A relevant aspect to consider is the fact that many of these producers are obtaining a current yield of just over a third of the potential for the cultivars that they possess, being the main reason for this the lack of technological implementation.

To review the geographical distribution of the four conglomerates, the delimitation of geomorphic units proposed by Börgel (Cortez et al., 2021) was used, finding blueberry orchards in the Coastal Plains, the Coastal Cordillera, the Plains of Sedimentation (terraces of the two exorheic Andean rivers of the region), the Central Plain and the Precordillera (figure 1). 


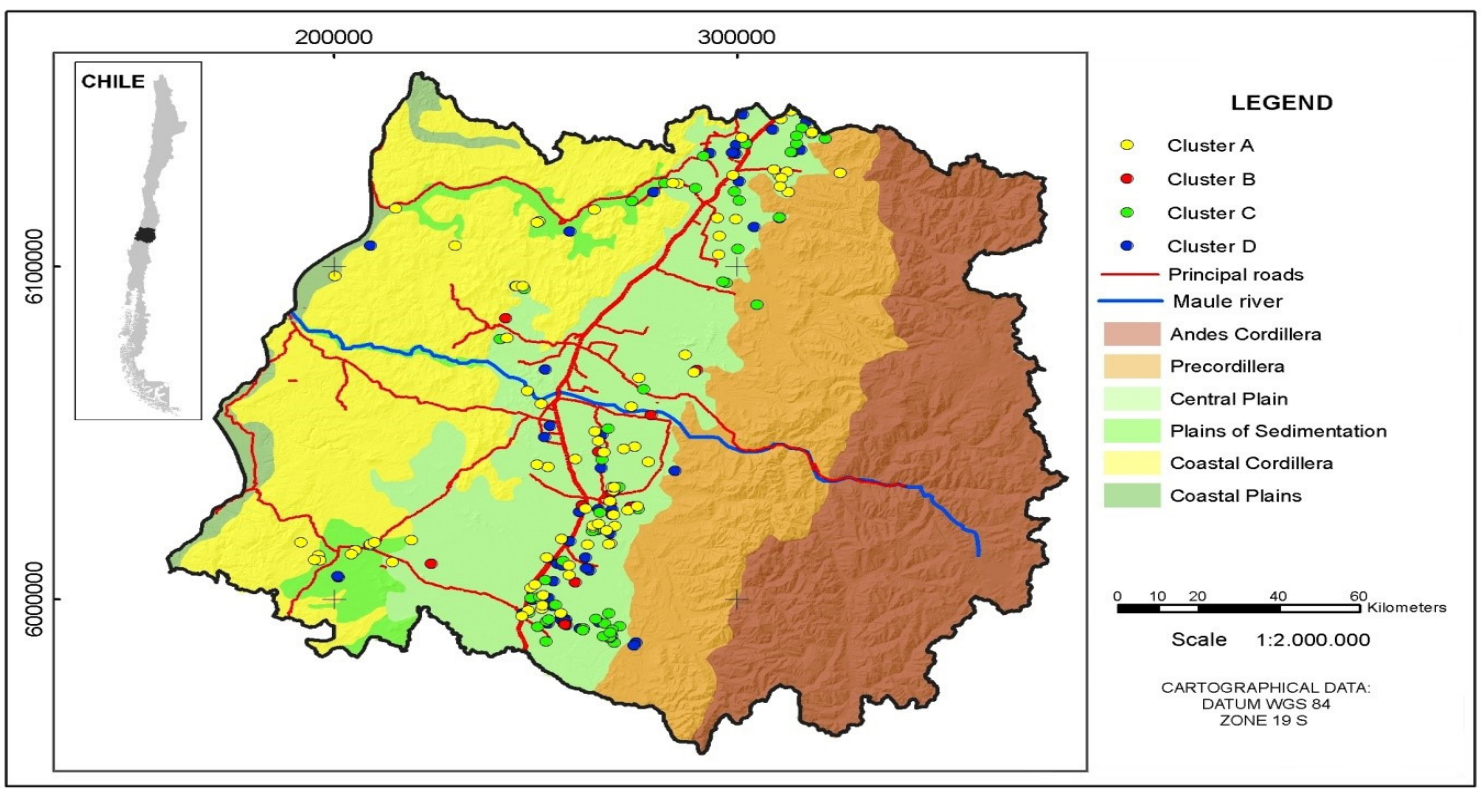

Figure 1. Geographical distribution of clusters of blueberry orchards.

The orchards corresponding to the Coastal Plains represent $0.49 \%$ of the regional total, those of the Coastal Cordillera 2.47 $\%$, in the Plains of Sedimentation there is $11.88 \%$, the Intermediate Depression concentrates the highest percentage with $83.16 \%$, while the remaining $1.98 \%$ is in the Precordillera. This concentration of producers in sectors that offer the most appropriate edaphic and climatic conditions for agricultural development is in line with what was proposed by De la Cruz (2008), in relation to the underlying mechanisms in the construction of a structure and the functioning of the dynamics resulting from the distributions of the productive activities in the territory. It is also interesting to note the trend of concentration of producing orchards at distances less than $20 \mathrm{~km}$ from the axis of the Pan-American highway (Route CH5), this trend is related to the advantage offered by the proximity to the most important road used for marketing of the fruits.

Figure 2 shows the geographical distribution by geomorphic units and the number of producers by TL in each of them. In the Intermediate Depression, there is a predominance of orchards corresponding to cluster A (37.5\%), a situation that is also registered in the Plains of Sedimentation (66.6\%), in the Coastal Plains $(100 \%)$ and in the Cordillera Coastal $(60 \%)$. For its part, the Precordillera has orchards mainly belonging to cluster D (50 $\%$ ), where there is a predominance of smaller productions that use the increasingly scarce flat areas in the narrow plains forming the rivers, prior to entering the Intermediate Depression.

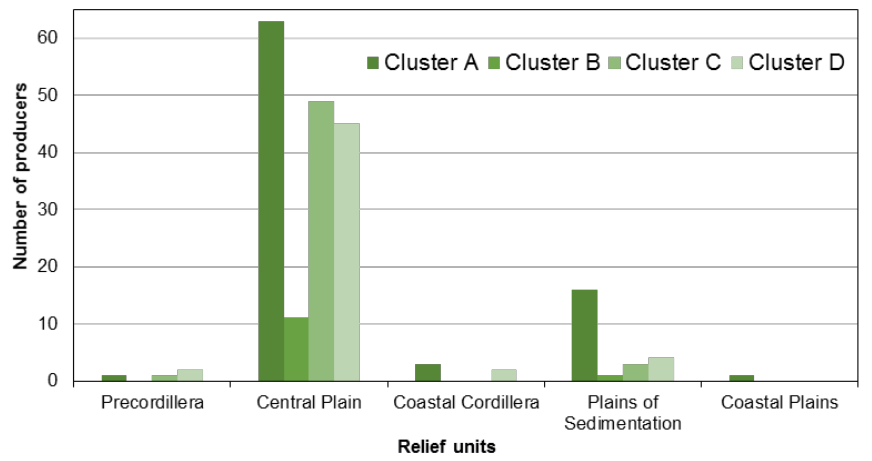

Figure 2. Distribution of blueberry orchards by cluster and relief units.
The majority group (cluster A) is present in the various territorial spaces, marking a strong predominance in the areas of influence of the Coastal Cordillera, especially in the Cauquenes basin. The existence of these larger orchards in one of the most economically depressed areas in the region is highlighted, since it is part of the sector called Secano Maule Sur included in the Development Plan for Lagging Areas, whose territory also includes the province of Cauquenes as well as the county of Empedrado. According to the data used in the preparation of this Development Plan, it is interesting that, among the 10 main occupations in the area, activities related to agriculture represent $23 \%$. Given the size of the orchards that comprise this group, it is possible to consider them as large companies, which, according to the same document, represent only $0.6 \%$ of the companies in the region, but employ $34.9 \%$ of the workers (GORE Maule, 2019). This reflects the strong differences between the production conditions of the orchards studied and the need to focus resources and efforts on those producers who require it.

From analysis of the different clusters obtained by means of the Ripley K function applied to all the blueberry-producing orchards in the region (figure 3), a clear trend towards concentration appears, mainly in the northern and southern sectors of the region, in addition to a singular concentration in the Cauquenes basin. In this way, the arrangement of most clusters along the Pan-American highway and other major communication routes reaffirms that structuring routes are an anthropic location factor that encourages the concentration of blueberry-producing orchards.

The identification of the tendency to the formation of conglomerates with certain related elements can facilitates the elaboration of policies and strategies, both for the public and private sectors, interested in strengthening agricultural productive activity, especially in a region closely linked to the rural areas (GORE Maule, 2019). When analyzing the impact of Chile's free trade agreements on exports of fresh fruit, it has been found that these agreements have been important instruments to provide greater market access for Chilean products (Fulponi \& Engler, 2013).

During the last decades, Chilean agri-food exports have achieved an important presence in the main world markets, increasing their volume and value significantly. However, not only Chile has 
6-7| | Rev. Fac. Agron. (LUZ). 2022, 39(1): e223902. January - March. ISSN 2477-9407.

increased its shipments and the total value of exports to destinations such as the United States, the European Union, and China, but other countries in the region and from other parts of the world compete with Chile in these markets, the growth of exports from these countries is affecting Chile's competitiveness and participation in the world market (Pérez \& Valdés, 2019).

Therefore, Fulponi \& Engler (2013) indicate that both the Chilean animal and plant health authority (SAG) and the Chilean export promotion agency (PROCHILE) are essential to promote Chile's reputation as exporter of quality products. However, they find that real market access did not always benefit all the sectors studied equally. These results highlight the importance of the design of territorial public policies. Considering that in Chile, according to the OECD (2019), producer support is mainly provided to small farmers, in the form of input subsidies and support for the formation of fixed capital, such as investments in irrigation at farm level and the provision of public goods; the results obtained in the present study can help in the development of support mechanisms at the territorial scale.

\section{Conclusions}

Blueberry producers in the Maule region can be grouped into 4 clearly differentiable conglomerates (A, B, C and D) based on the studied parameters of production size, age and technological level (TL) of the orchards, the first of which appears as the most decisive at the time of make up the groupings.

The TL2 is clearly the predominant technological level between all the clusters identified, followed by TL1 (in clusters B, C and D). TL3 is the technological level less predominant (excepting in cluster A).

The spatial distribution of the producing orchards is not a matter of variables as size or age or TL, it's a matter of communication facilities, for inputs and outputs management and also of agroecological conditions (climate, soil, relief) for blueberries cultivation among others aspects.

Spatial agglomeration identification and measurement are highvalue inputs for public policies design and implementation. In this sense, inputs mentioned can improve focus of public efforts and private investments in the area.

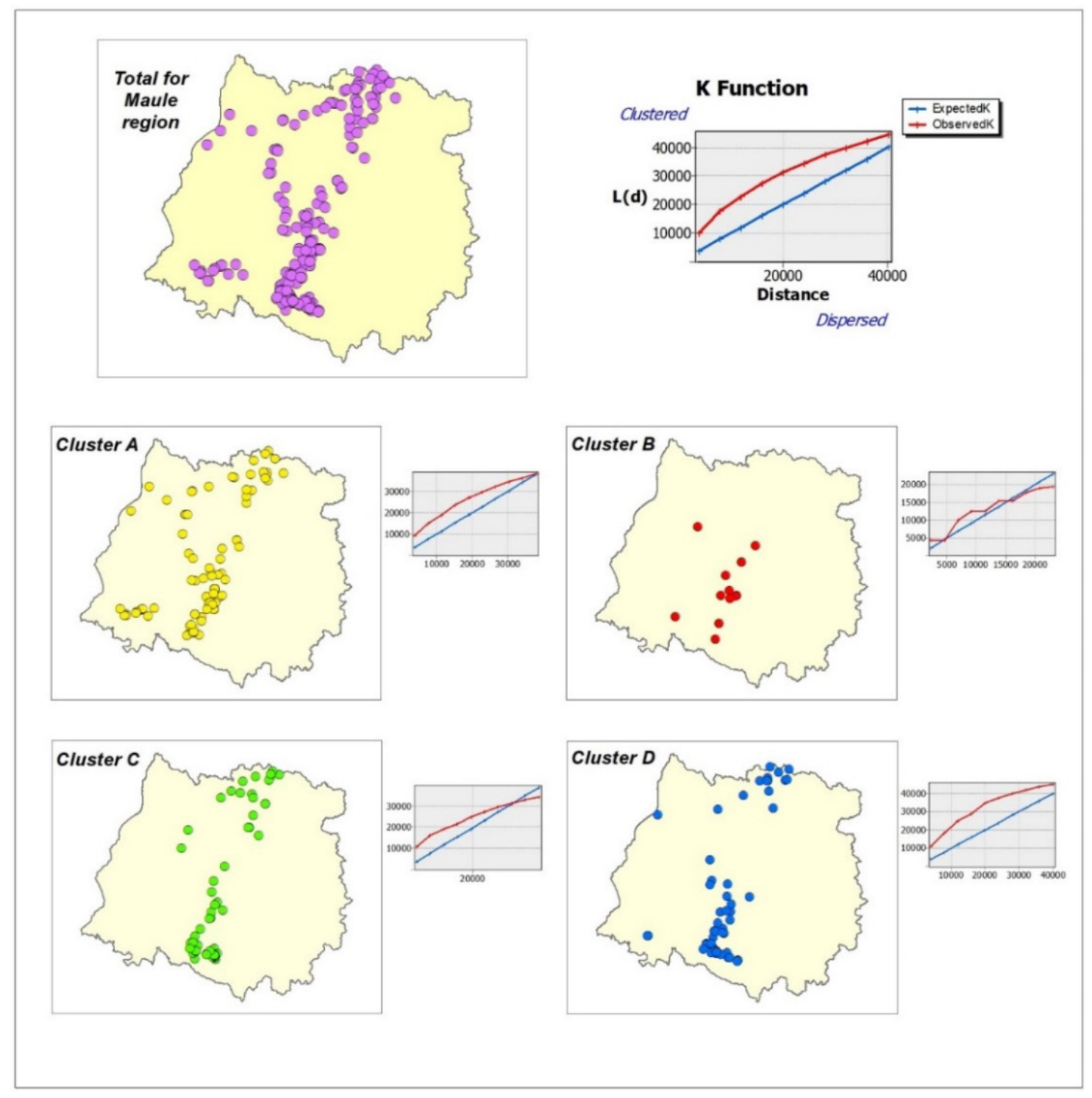

Figure 3. Spatial correlation between orchards for the identified clusters. 


\section{Literature cited}

Acosta, L., Rounsevell, M., Bakker, M., Van Doorn, A., Gómez-Delgado, M. \& Delgado, M. (2014). An Agent-Based Assessment of Land Use an Ecosystem Changes in Traditional Agricultural Landscape of Portugal. Intelligent Information Management. (6), 55-80. https://doi.org/10.4236/ iim.2014.62008

Almonacid, F. (2018). El sur de Chile como parte de cadenas globales de valor, 1985-2016: Economía regional y producción de arándanos. Revista de Estudios sobre Despoblación y Desarrollo Rural. (25), 131-158. https:// cutt.ly/vnP7RYD

Borja-Bravo, M., Reyes-Muro, L., García Salazar, J. y Almeraya-Quintero, S. (2016). Tipología de productores de uva (Vitis vinífera L) en Aguascalientes. Revista mexicana de Ciencias Agrícolas. 7(2), 249-261. https://cutt.ly/vnP7SWl

Carmona, A. y Nahuelhual, L. (2009). Tipificación y caracterización de sistemas prediales: caso de estudio en Ancud, Isla de Chiloé. Agro Sur. 37(3):189199. https://cutt.ly/ynHcihK

Carpio, D. y Urbano, B. (2019). Caracterización del uso del coaching ejecutivoorganizativo en la cadena de valor agroalimentaria. Revista de la Facultad de Agronomía de LUZ 36(2), 162-187. https://cutt.ly/rnP7Lza

Carrillo, B., Moreira, V. y González, J. (2011). Caracterización y tipificación de sistemas productivos de leche en la zona centro-sur de Chile: un análisis multivariable. IDESIA (Chile). 29(1), 71-81. https://cutt.ly/7nP7Xm5

Castellanos, C., Castellanos, J., Machado, N., Vila, Z. y Barbosa, G. (2012). Contribución de los clústeres a la competitividad de las empresas. Técnica Administrativa. 11 (50), https://cutt.ly/unP7V9i

Chilean Blueberry Committee. (2020). Why Blueberries from Chile? https://cutt. ly/lnP71ty

Cortez, D., Herrera, S., Araya-Osses, D., Caroca, C., Padilla, R., Uribe, J.M. \& Paneque, M. (2021). Topoclimatic zoning of continental Chile. Journal of Maps, 17(2), 114-124. https://doi.org/10.1080/17445647.2021.1886188

De la Cruz, M. (2008). Métodos para analizar datos puntuales. En: Maestre, F.T., Escudero, A. y A. Bonet (Eds). Introducción al Análisis Espacial de Datos en Ecología y Ciencias Ambientales: Métodos y Aplicaciones. (76127). Editorial Dykinson S.L.

Dominicis, L., Arbia, G. \& De Groot. H. (2007). The spatial distribution of economic activities in Italy. [PDF Document] https://cutt.ly/JnP77UA

Duque, J., Rey, S. \& Gómez, D. (2009). Identifying Industry Clusters in Colombia Based on Graph Theory. Ensayos sobre Política Económica. 27(59):1445. https://cutt.ly/lnP5wJ8

Duranton, G. \& Overman, H. (2005). Testing for localization using microgeographic data. Review of Economic Studies, 72(4), 1077-1106. https:// cutt.ly/YnP5r25

Fernández, F.J., Blanco, M., Ponce, R.D., Vásquez-Lavín, F. \& Roco. L. (2019). Implications of climate change for semi-arid dualistic agriculture: a case study in Central Chile. Regional Environmental Change, (19), 89-100. https://doi.org/10.1007/s10113-018-1380-0

Fulponi, L. \& Engler, A. (2013). The Impact of Regional Trade Agreements on Chilean Fruit Exports. OECD Food, Agriculture and Fisheries Papers [Archivo PDF] https://doi.org/10.1787/5k3z0kd43z5f-en

Garrocho, C., Álvarez-Lobato, J. y Chávez, T. (2012). Aglomeración espacial de establecimientos comerciales en un centro tradicional de negocios. Economía Mexicana Nueva Época, 21(1), 93-131. https://cutt.ly/mnP5s2I

González, J., Villavicencio, A. y Morales, C. (2016). Línea Base de Pequeños Productores de Berries en la Zona Centro Sur Contextos productivo, económico y comercial. Villa Alegre. Ministerio de agricultura- INIA https://cutt.ly $/ 3 \mathrm{nP} 5 \mathrm{gEi}$

González, S., Guajardo, L., Almeraya-Quintero, S., Pérez-Hernández, L. y Sangerman-Jarquín, D. (2018). Tipología de productores de maíz en los municipios de Villaflores y La Trinitaria, Chiapas. Revista Mexicana de Ciencias Agrícolas, 9(8), 1763-1776. https://cutt.ly/xnP5ks6

Gobierno Regional del Maule. (2019). Plan de Desarrollo para Zonas Rezagadas "Secano Maule Sur" 2019-2022. https://cutt.ly/UnP5v90

Guerrero, J., Meriño-Gervichevich, C., Ogass, K., Alvarado, C. y Sobarzo, V. (2015). Características de calidad y condición de frutos de avellano europeo (Corilus avellana L.) cv. Barcelona en la zona centro-sur de Chile. Revista de la Facultad de Ciencias agrarias de Uncuyo, 47(2), 1-14. https://cutt.ly/VnP5Wnh
Hair, J.F., Black, W.C., Babin, B.J. \& Anderson, R.E. (2010). Multivariate data analysis. Pearson.

Lobos, G. (2006). Tercer Informe: Consultoría de estudio e identificación de clústeres exportadores regionales (CER). El caso de la Región del Maule [Archivo PDF] https://cutt.ly/BnP5TIZ

Maturana, F., Sepúlveda, U., Prada, J., Fuenzalida, M. y Stafolleri, J. (2019). Trayectoria y coevolución funcional del empleo en las ciudades chilenas. Anales de Geografia de la Universidad Complutense, 39(2), 359-385. https://doi.org/10.5209/aguc.66943

Marcon, E. \& Puech, F. (2003). Evaluating the geographic concentration of industries using distance-based methods. Journal of Economic Geography. 3(4):409-428. https://doi.org/10.1093/jeg/lbg016

ODEPA y CIREN. (2019). Catastro Frutícola. Principales Resultados Región del Maule. Oficina de Estudios y Políticas Agrarias del Ministerio de Agricultura y el Centro de Información de Recursos Naturales, Santiago, Chile. https://cutt.ly/DnHcIJW

OECD. (2019). Agricultural Policy Monitoring and Evaluation 2019. OECD Publishing. https://cutt.ly/WnP5IwA

Ormazábal, Y., Mena, C., Cantillana, J. y Lobos, G. (2020). Caracterización de predios productores de arándanos (Vaccinium corymbosum), según nivel tecnológico. El caso de la región del Maule-Chile. Información. Tecnológica, 31(1), 41-52. https://cutt.ly/4nP5HC9

Ortega-Colomer, F.J., Molina-Morales, F.X. \& Fernández de Lucio, I. (2016). Discussing the Concepts of Cluster and Industrial District. Journal of technology management \& innovation, 11(2), 139-147. https://cutt.ly/ TnP5LhV

Pérez, C. (2011). Técnicas de segmentación. Conceptos, herramientas y aplicaciones. Gaceta Grupo Editorial.

Pérez, R. y Valdés, A. (2019). Análisis de la evolución y desempeño agroexportador de Chile, 2000- 2017. [PDF Document] https://cutt.ly/gnHcv7y

Retamales, J. \& Hancock. J. (2012). Blueberries. CAB International.

Riffo, M. (2018). Impactos espaciales y socioeconómicos de la Vitivinicultura en Chile y Argentina. Revista Geográfica, (143), 163-210. https://cutt.ly/ AnP5Cxl

Rubio-Hurtado, M.-J. y Vilà-Baños, R. (2017). El análisis de conglomerados bietápico o en dos fases con SPSS. REIRE. Revista d'Innovacio i Recerca en Educació, 10(1), 118-126. https://cutt.ly/BnP5BxC

Rosenberg, A. \& Turvey, C.G. (1991). Identifying management profiles of Ontario swine producers through cluster analysis. Review of Agricultural Economics. (13), 201-213. https://doi.org/10.2307/1349637

Sarricolea, P., Herrera-Ossandon, M. \& Meseguer-Ruiz, Ó. (2017). Climatic regionalisation of continental Chile. Journal of Maps, 13(2) ,66-73. https://doi.org/10.1080/17445647.2016.1259592

Satish, S.M. \& Bharadhwaj, S. (2010). Information search behaviour among new car buyers: A two-step cluster analysis. IIBM Management Review, (22), 5-15. https://doi.org/10.1016/j.iimb.2010.03.005

Soza-Amigo, S. (2011). Encadenamientos y similitudes estructurales para las regiones de Chile. Revista de Análisis Económico, 26(2), 81-111. https:// cutt.ly/2nP5Msc

Tapia, L., Aramendiz, H., Pacheco, J. y Montalvo, A. (2015). Cluster agrícolas: un estado del arte para los estudios de competitividad en el campo. Revista de Ciencias Agrícolas, 32(2), 113-124. https://doi.org/10.22267/ rcia.153202.19.

Van Doorn, A. \& Bakker, M. (2007). The destination of arable land in a marginal agricultural landscape in South Portugal: An exploration of land use change determinants. Landscape Ecology, (22), 1073-1087. https://doi. org/10.1007/s10980-007-9093-7

Van de Steeg, J.A., Verburg, P.H., Baltenweck, I. \& Staal, S.J. (2009). Characterization of the spatial distribution of farming systems in the Kenyan Highlands. Applied Geography, 30(2), 239-253. https://doi. org/10.1016/j.apgeog.2009.05.005

Vidal-Suñé, A. y Pezoa-Fuentes, C. (2012). Identificación de clúster productivos: aplicación a la economía chilena. Revista de Ciencias Sociales (Venezuela), 13(3), 482-497. https://doi.org/10.31876/rcs.v18i3.24992 